\title{
Chapter 3 Preventing a Repetition of the Great War: Responding to International Terrorism in the 1930 s
}

\author{
Michael D Callahan"
}

On 9 October 1934, King Alexander I of Yugoslavia was assassinated as he arrived in Marseilles to begin a state visit to France. ${ }^{1}$ Louis Barthou, the French foreign minister, was wounded during the chaos and died later. Evidence quickly established that anti-Yugoslav terrorist groups based in Italy and trained in Hungary had carried out the attack. The terrorists' ultimate goal was to destabilize the multi-ethnic Yugoslavia and create new nation states. Much like the shooting of the Archduke Franz Ferdinand at Sarajevo twenty years before, Alexander's murder sparked an international crisis that threatened the peace of Europe. France supported Yugoslavia; Italy the Hungarians. In the background were alliances and individual states interested in either defending or changing the European status quo. All the ingredients of the July Crisis of 1914 seemed suddenly there again.

While these two terrorist attacks had important similarities, their repercussions were very different. According to its Covenant, the main purposes of the League of Nations were 'to promote international co-operation and to achieve international peace and security.' These central aims were in fact accomplished in 1934, an achievement that represents the League at its most effective. With strong leadership from Britain and France, the League made it possible for states to adopt a unanimous resolution that preserved the peace that all sides wanted.

During its successful mediation the League Council decided to confront the serious problem of international terrorism. Jurists and officials from several countries would spend nearly three years exploring ways to classify specific terrorist acts, and conspiracies to commit them, as international

* Professor of History and Frances Willson Thompson Professor of Leadership Studies, Kettering University.

1 This essay draws on a larger recent study. For more, including a list of all references and archival sources, see Michael D Callahan, The League of Nations, International Terrorism, and British Foreign Policy, 1934-1938 (Palgrave Macmillan 2018).

2 Covenant of the League of Nations (adopted 28 June 1919) 225 CTS 195. 
crimes. These efforts were significant milestones in the history of modern international law and legal procedure. Yet the League's legal response to terrorism was designed to deter or punish emulators of Alexander's assassination, not contend with the sorts of challenges that Adolf Hitler posed. In the end, few governments supported the organization's anti-terrorism project in itself. In contrast to the League's success in helping states use the security provisions of the Covenant and find common ground through diplomacy to preserve peace in 1934, the collective attempt from 1935 to 1938 to combat state-supported terrorism through the development of experimental legal methods and institutions illustrates the increasing limits on the organization's effectiveness.

'The King and M. Barthou are dead and the future is darkly uncertain', The New York Times declared the day after the terrorist attack at Marseilles. All of Europe feared 'grave complications.' In London, The Times called it 'a horrible crime' that 'shocked the conscience of civilised Europe.' According to Le Temps in Paris, the shootings were a 'criminal act' that could have 'profound political repercussions.' Since Alexander's assassination was captured on film, it was not long before cinemas across Europe and North America were adding to the sense of deepening international crisis. ${ }^{3}$ Given the sensationalist nature of the newsreels, the British government warned the film industry against showing unedited versions in the United Kingdom. ${ }^{4}$ In France, Yugoslavia, and elsewhere the newsreels were eventually banned or heavily censored. Few needed the press pointing out that 'no one forgets tonight that it was the assassination in Sarajevo that started the World War. 5

Memories of 1914 underpinned the overall sense of dread in the first few volatile days after the terrorist attack at Marseilles in 1934. Govern-

3 The New York Times (New York, 10 and 11 October 1934) 1 and 2; The Times (London, 10 October 1934) 15; Le Temps (Paris, 11 October 1934) 1; and 'Alexander Murdered' (9 October 1934) Universal International News, Newsreels 1932-35, DVD50, compiled by Steven Schoenherr, available at $<$ http://history.sandiego.edu/ gen/newsreels $>$ accessed 20 June 2018.

4 Meeting of the Cabinet (17 and 24 October 1934) National Archives (United Kingdom) CAB 23/80 and 'Assassination of King Alexander and M. Barthou: Cinematographic Film. Memorandum by the Home Secretary' (22 October 1934) CAB $24 / 251$.

5 The New York Times (New York, 10 October 1934) 15. 
ments quickly reexamined their policies. Italy and Hungary scrambled to deny responsibility and divert attention, even as evidence increasingly implicated both. If Yugoslavia made formal accusations or issued any sort of ultimatum, a violent reaction would be almost inevitable.

The Marseilles attack also made the larger question of terrorism a matter of serious public and private debate. While most states routinely condemned political violence and expected the French police to conduct a criminal investigation, some now began to advocate international action against terrorist organizations. Others feared alienating Italy or provoking Hungary, thereby risking an end to plans for greater political cooperation in Europe, especially in containing Nazi Germany and maintaining peace. By 1934 most European statesmen understood that the League could itself never require such international action, particularly not of a great power determined to oppose it.

The news from France shocked Britain. After receiving intelligence substantiating Yugoslavia's charges against Italy and Hungary, British Foreign Secretary Sir John Simon exerted British influence to urge calm. In a speech timed to coincide with Alexander's funeral, Simon called political assassination 'not only the most wicked, but the most stupid of political crimes' because it seldom accomplished its intended result. ${ }^{6} \mathrm{He}$ also was certain that no state could want to repeat the catastrophe of 1914-1918.

Now we have had the bitter experience of four years of war, and when we survey this stricken and shattered world, we can realise not only the horror, but the uselessness of slaughter. The antiquated method of blood-letting as a cure for national fever is rejected, not only by conscience, but by the experience of mankind. ${ }^{7}$

But Britain likewise wanted no new commitments in Europe and had no intention of addressing the complicated question of state-supported terrorism. The British government's policy in October 1934 was therefore to do what they thought should have happened in July 1914: joining other great powers to urge restraint and keep the peace despite a provocative act of terrorism.

French officials were in a quandary. France and Yugoslavia were allies under terms of a Treaty of Friendship signed in 1927. The new French foreign minister, Pierre Laval, worried about undermining the League, worsening Yugoslavia's relations with Italy, or having to take sides publicly be-

6 For the text of the speech, see The Times (London, 20 October 1934) 14.

7 ibid. 
tween Belgrade and Rome. Like Britain, France was willing to placate both the Italians and Hungarians in order to preserve peace, but was finding this difficult in the face of growing pressure from the Yugoslavs and their other allies in Eastern Europe.

The Yugoslav government demanded accountability for Alexander's murder as well as an international effort to prevent future terrorist attacks. In November 1934 the Yugoslav government filed a formal request with the League to address the 'odious crime of Marseilles. ${ }^{8}$ This appeal put renewed focus on international law and the security provisions of the League Covenant. The kingdom did not call on League members to fulfill their obligations under Article 10 to respect and preserve its 'territorial integrity and existing political independence' against an act of 'external aggression.' Instead the Yugoslavs cited Article 11(2), exercising their 'friendly right' to bring to attention 'any circumstance' threatening 'to disturb international peace or the good understanding between nations upon which peace depends.' Without mentioning Italy or even implicating the Hungarian government, the Yugoslavs accused 'certain Hungarian authorities' of assisting the terrorists who murdered Alexander. As a consequence, Yugoslavia declared that peace with Hungary was now endangered. While the complaint insisted that the circumstances of the crime 'must be completely brought to light', it identified only 'the responsibility of the Hungarian authorities' as requiring 'just punishment.' Only the Council could 'restore confidence in international morality and justice' in this situation. But the attack at Marseilles exposed the larger problem of state-supported terrorism which was a threat to 'any civilised nation.'

This is not the case of a political murder which is the work of an isolated individual, nor of shelter given to political emigrants; the question involved is that of drilling and training on the territory of a foreign State of professional criminals intending to commit a series of outrages and assassinations for a specific political purpose. ${ }^{10}$

The Yugoslavs warned that if the League, 'the guardian of peace and of the international morality on which peace depends', did not confront this dangerous problem and attempt to put an end to such crimes, "[a]n era of anarchy and international barbarism would overwhelm the civilised world. ${ }^{11}$

8 LoN, Council, 83rd (extraordinary) session, Annex 1523: The Government of Yugoslavia to the League of Nations (22 November 1934) 15 LNOJ 1765-1766.

9 ibid 1766.

10 ibid.

11 ibid. 
Reactions varied. Both Romania and Czechoslovakia supported Yugoslavia. Each insisted that its own relations with Hungary were also endangered, as were 'the general conditions on which peace in Central Europe depends.' Hungary protested that it was the victim of 'the most farfetched accusations,' which were 'not only full of serious dangers for the ordinary relations between certain States of Europe' but were also 'capable of affecting even the peace of the world'. It insisted on an opportunity to 'defend its honour' at Geneva and reminded the Council of its right under Article 4 of the Covenant to address 'any question' concerning global peace. Italy backed Hungary's demand that the Council consider the matter as soon as possible. ${ }^{12}$

The League Council helped to end this dangerous international crisis. Despite initial reluctance, London agreed that Anthony Eden, the British member of the League Council, would serve as rapporteur for the dispute. The Council met from 5 to 11 December. For two days the representatives of Yugoslavia and Hungary, along with other members of the League, took turns speaking in an open forum. All appealed to public opinion, tried to score political points at home and abroad, staked out negotiating positions, and attempted to bend the League's moral authority to serve their national interests. ${ }^{13}$ The Soviet representative insisted 'post-war terrorism' was 'an immense danger to the maintenance of international relations and general peace' and the League needed 'to work out measures for combating this international evil. ${ }^{14}$ None of the organization's member states wanted war, but 1914 had taught them that war could come through miscalculation rather than intent. Publicly addressing disputes at Geneva was meant to diminish that possibility. Council speeches did not resolve the crisis, but they exposed areas of common ground and created conditions necessary to make subsequent private negotiations successful.

The Council's resolution adopted during a special midnight session made specific and far-reaching proposals for settling the Yugoslav-Hungarian dispute. Eden's brief report to the Council that night illustrates why the League's peacekeeping functions were successful in 1934. ${ }^{15}$ As with all of the Council's previous major decisions, the settlement he recommended was the result of a process of conciliation and compromise. He reminded

12 ibid Annex 1523a, 1523b, and 1523c.

13 LoN, Council, $83^{\text {rd }}$ (extraordinary) session, $3^{\text {rd }}$ and $4^{\text {th }}$ meeting $(7$ and 8 December 1934) 15 LNOJ 1691-1842.

$144^{\text {th }}$ meeting (8 December 1934) ibid, 1734.

$156^{\text {th }}$ meeting (10 December 1934) ibid, 1759-1760; 14 League of Nations Monthly Summary 283. 
the public that the League had a circumscribed role in resolving international disputes. The Council was not a parliamentary but a diplomatic body. The League relied on the information that sovereign states, acting in good faith, provided the organization and on the willingness of member states to carry out international obligations they freely accepted.

It must be observed that the Council is not a court of justice. It has no means at its disposal for undertaking judicial enquiries. Its function is to assist the parties to re-establish the political relations which are desirable between Members of the League. ${ }^{16}$

Eden offered the carefully worded conclusion that even 'if the whole question of responsibility has not been completely elucidated', there was enough evidence to convince him that 'certain Hungarian authorities may have incurred, at any rate through negligence, certain responsibilities relative to acts connected with the preparation of the Marseilles crime. For this reason, the Hungarian government should punish anyone 'whose culpability may be established' and report 'the measures it takes to this effect' to the Council. ${ }^{17}$ This tightly limited and highly equivocal finding of guilt met Yugoslavia's demand for achieving a measure of accountability for Alexander's murder.

Another reason for the League's success was that Britain and France had satisfied Yugoslavia's other demands as well. To prevent the sort of terrorist acts witnessed at Marseilles in the future, Eden noted that the French delegation had presented a series of propositions on the subject, including specific suggestions for 'the effective suppression of political crimes of an international character' and the creation of an international criminal court to try accused terrorists. Admitting that the rules of international law concerning the repression of terrorist activity were not yet 'sufficiently precise to guarantee efficiently international co-operation in this matter', he suggested that a 'committee of experts' study the problem and produce a preliminary draft convention 'to assure the repression of conspiracies or crimes committed with a political or terrorist purpose. ${ }^{18}$ While the British government previously opposed discussion of an anti-terrorism convention, London was now willing to go along if it resolved the current crisis peacefully and did not oblige Britain to do anything. This committee would have members from Britain, France, Italy, and the Soviet Union, the

16 ibid 1759.

17 ibid.

18 ibid. 
four most powerful states in the League. Several other governments interested in the question were invited to participate, including Belgium, Chile, Hungary, Poland, Romania, Spain, and Switzerland. The French proposals would serve as the starting point of the committee's work.

The Council's settlement of the Hungaro-Yugolsav dispute was greeted with genuine relief and widespread praise. Behind the scenes, the League Secretariat began the work necessary to carry out technical aspects of the Council's resolution. The secretary-general, Joseph Avenol of France, also used his personal influence to put pressure on the Hungarians and ensure the final outcome. Eden later concluded that the Yugoslav appeal to Geneva 'was a dispute of the type which the League of Nations was well qualified to handle.' ${ }^{19}$ In announcing the results to parliament, Simon called it a victory for the forces of 'reconciliation and appeasement', moderation, and international cooperation. 'But there can be no doubt', he declared, 'that the favourable position which has been reached from a situation which so recently appeared to threaten grave consequences, is due first and foremost to the existence and the effective use of the League of Nations.20

The League's achievement, however, had been neither inevitable nor easy. Keeping the peace in 1934 depended on the leading members of the Council. France worked to pacify its Eastern European allies and Laval was responsible for hammering out many details of the final resolution. Italy ultimately gave only half-hearted support to Hungary in favor of other priorities, particularly the promise of an accord with France. Britain portrayed itself as impartial and Eden was willing to disappoint both sides of the dispute, particularly the Yugoslavs, in order to keep everyone calm and to promote international cooperation. Other states also urged cooperation while some took the opportunity to defend their opposing interpretations of the Treaty of Versailles. All sides were willing to ignore the course of justice in order to serve the cause of peace by overlooking Italy's complicity in Alexander's murder. Avoiding another needless war in Europe remained the overriding moral imperative.

The Committee for the International Repression of Terrorism first met in Geneva in early 1935 . Using the French proposal as a starting point, the

19 Earl of Avon (Anthony Eden), The Eden Memoirs: Facing the Dictators (Houghton Mifflin 1962) 132.

20296 House of Commons Debates (11 December 1934) cols 213-214. 
Committee approved several articles of an anti-terrorism convention. Some of the Committee's ideas were bold and innovative, others only made a confusing and difficult undertaking more so. These deliberations demonstrated that the League could foster international cooperation, but they also exposed deep divisions between - and within-member states over the definition of 'terrorism', the limits of extradition law, the rights of political refugees, and the practicality of an international criminal court. ${ }^{21}$

While initial reaction to the Committee's accomplishments was generally favorable, Nazi Germany's unilateral rearmament and remilitarization of the Rhineland, Italy's attack on Ethiopia, and the outbreak of civil war in Spain affected the way many governments approached the subject of international terrorism and altered attitudes toward the League of Nations in general. Most British officials never supported an international criminal court. Many also were dubious about adopting new domestic legislation to criminalize international terrorism. Yet it was primarily because Eden had proposed the Council's resolution in the first place that the British government agreed to help draft an international anti-terrorism convention, but were careful not to promise to ratify such a convention. ${ }^{22}$

The League's committee on terrorism held its second session in early 1936. All of the original members, including Italy and Hungary, participated. Their efforts, however, became increasingly technical and symbolic as governments considered other threats to global peace and security more important. Still, they drafted two conventions: one to criminalize international terrorism and the other to establish an international criminal court. $^{23}$ The first convention raised particularly difficult questions in Britain. The Home Office was convinced that parliament would never accept an anti-terrorism convention requiring any significant changes to British law. Eden, however, now foreign secretary, saw diplomatic benefit in cooperating in drafting the conventions and convening a diplomatic conference to consider them, even if ultimately the British government refused to sign or ratify either one. When in late 1936 several other states at the League Assembly attempted to impede the organization's anti-terrorism project, France and Britain joined to give the experts one last chance to revise the conventions. Preserving the prestige of the League and carrying

21 Report to the Council on the First Session of the Committee CRT (8 May 1935) C.184.M102.1935.V.

22 See Callahan (n 1) ch 7.

23 Committee for the International Repression of Terrorism: Report to the Council Adopted by the Committee on January 15 th, 1936 CRT (10 February 1936) A.7.1936.V [C.36(I).1936.V]. 
out the Council's resolutions still mattered to both great powers, even if the anti-terrorism project itself did not. ${ }^{24}$

The Committee's third and final session was in April 1937. ${ }^{25}$ After more than two years of work, the Council accepted the revised drafts and agreed to summon a diplomatic conference on terrorism in November, a decision that fulfilled all conditions of the Hungaro-Yugoslav settlement. ${ }^{26}$ Eden could claim success, but he, and the rest of Europe, was already dealing with larger concerns. When Britain's attorney-general, solicitor-general, and home secretary continued to see legal and political difficulties in the latest draft anti-terrorism convention, Eden quietly abandoned it. ${ }^{27}$

The International Conference on the Repression of Terrorism opened in Geneva on November 1, 1937. ${ }^{28}$ Thirty-five member states, along with an observer from Brazil, attended. Instead of further delaying or diluting the organization's efforts, the delegates produced two conventions that largely preserved — and in certain respects even strengthened-the expert committee's drafts. Determined delegates from France and a few other countries took control of the conference to accomplish their own diplomatic objectives. A number of jurists who served as delegates remained committed to innovative ideas for combating terrorism, particularly those concerning conspiracy and incitement to commit terrorist acts. They also continued to advocate incremental reforms, including those regulating firearms and ammunition, enhancing international police cooperation, and tightening passport controls. The chairman of the conference, Henri Carton de Wiart, formerly the prime minister and minister of justice of Belgium, used his opening speech to advocate the emerging modern concept of a shared global community that needed to undertake active and collective legal responses to new and different threats to security. He observed that

we cannot but realise with shame and disquiet how advancing knowledge and improved communications have served in their turn to menace the security of persons and property and helped to promote acts designated by that new term 'terrorism' - acts which, by reason of their gravity and contagious nature, are prejudiced not only to the interests

24 See Callahan (n 1) ch 8.

25 Report Adopted by the Committee on April 26 th, 1937 CRT (26 April 1937) C.222.M.162.1937.V.

26 League Council, 97th session, 4th meeting (27 May 1937) 18 Official Journal 308310.

27 See Callahan (n 1) ch 9.

28 LoN, Proceedings of the International Conference on the Repression of Terrorism: Geneva, November 1st to 16th, 1937 (Geneva 1938) C.94.M.47.1938.V. 
of individuals as such or of one or more specific States, but may affect mankind as a whole.

Others, including the Czech delegate, strongly agreed and used the conference as a means to bolster the League's ability to work collectively to defend the interests of smaller states through 'the organisation of international action against terrorism.' France, Romania, Yugoslavia, and Spain worked together to strengthen both conventions or ensure that they were not to change much from the preliminary texts that had emerged the previous April. In general, the states most threatened by internal and external enemies in late 1937 did the most to shore up both drafts.

Twenty-five governments representing peoples from across Europe, Latin America and the Caribbean, the Middle East, and Asia signed 'The Convention for the Prevention and Punishment of Terrorism. According to Article 1, 'acts of terrorism' were defined as 'criminal acts directed against a State and intended or calculated to create a state of terror in the minds of particular persons, or a group of persons or the general public'. The list of criminal offenses included not only attempts to kill political leaders, but also 'any wilful act calculated to endanger the lives of members of the public.29

Most states, however, opposed the proposed international criminal court. 'The Convention for the Creation of an International Criminal Court' was eventually signed by only thirteen states, including Belgium, Czechoslovakia, France, Greece, the Netherlands, Romania, Spain, Turkey, the USSR, and Yugoslavia. ${ }^{30}$ Since Britain and a number of other states strongly opposed linking the court to the League, the conference decided that the Permanent Court of International Justice should select the judges and the new court's seat should be at The Hague, not Geneva. After signing it, the Czech delegate attempted to put the best face on it he could by observing that the fact that states representing 'upwards of a hundred million persons' had accepted the idea of an international criminal court was 'a landmark in the development of international criminal law. ${ }^{31}$ France made sure to remind everyone that both conventions were based on a

29 Convention for the Prevention and Punishment of Terrorism (adopted 16 November 1937) (1938) Série de publications de la Société des Nations / 5 SdN Doc C.546.M.383.1937.V.

30 Convention for the Creation of an International Criminal Court (adopted 16 November 1937) (1938) Série de publications de la Société des Nations / 5 SdN Doc C.547(1).M.384(1).1937.V.

31 Proceedings of the International Conference on the Repression of Terrorism (n 28) 178. 
French proposal and maintained an ongoing interest in the states that signed them. ${ }^{32}$

In the end, India was the only signatory to ratify the anti-terrorism convention. None ratified the court convention. Britain did not sign either one. Denmark considered adhering to both conventions early in 1939, but after consulting the British government did not. ${ }^{33}$ Neither convention ever went into force. Nonetheless, delegates from smaller powers, defended both conventions. For them, the League's anti-terrorism project was a success, if only in a technical and symbolic sense. Romania called the conclusion of the two conventions 'a red-letter day' for the development of international criminal jurisdiction and international cooperation. ${ }^{34}$ The Yugoslav delegate reminded everyone that the League had not only settled the international crisis resulting from the terrorist attack at Marseilles in 1934, but had fulfilled its duty to address the underlying cause of that crisis. Yet, for the Yugoslavs, the value of the conventions was 'primarily as a moral achievement' and 'a demonstration of international solidarity', not as effective instruments to suppress and punish state-supported terrorism. In a reference to the darkening international climate, he expressed a hope that the 'moral force and preventative influence' of the two conventions might serve 'the future happiness of generations more fortunate than our own.'35

From its beginnings the League of Nations defined 'peace' and 'security' in terms of the experience of the First World War. In order to achieve this peace and security, as well as promote international cooperation, League member states promised not to resort to war, to foster good relations between governments, to observe international law, and to respect all treaty obligations. The vast majority of the world's sovereign states were League members by 1934. But both within and outside of the organization some observed that preventing war required an understanding of the root causes of political instability. Peace depended on changing the way that states viewed themselves in relation to each other. The League of Nations handled dozens of international disputes, many of which centered on the

32 French Foreign Ministry to League (16 June 1938) United Nations Archives at Geneva, 3A/33882/31742.

33 Callahan (n 1) 220.

34 Proceedings of the International Conference on the Repression of Terrorism (n 28) 179180.

35 ibid 175-76. 
Balkans. Indeed, managing the myriad sources and symptoms of political violence in Southeastern Europe was vital to the organization from its origins. Yet the League's peacekeeping authority was always circumscribed by international power constraints beyond its control.

Many statesmen in the interwar period were convinced that if the League of Nations had a role to play in international relations, it was to help maintain the peace that all governments genuinely desired, even if this required pressing smaller states to accept unpleasant concessions, sweeping inconvenient truths under the rug, and leaving intractable issues to be sorted out in the indefinite future. The settlement of the dispute between Yugoslavia and Hungary exemplified this conception of the League's utility. The League proved it could carry out its essential peacekeeping duty, and could do so in constructive and often creative ways. Yet as with earlier settlements under the auspices of the League, successful resolution of the international crisis of late 1934 was imperfect and limited. It was the sort of diplomatic compromise that states aligned on all sides of an international dispute could choose to accept when genuinely determined to prevent war for fear of where it might lead. Such determination was absent in 1914 and would be again in 1939.

Blaming the League for failing to accomplish what was always impossible, or condemning its most powerful members for not reading Hitler's mind, has obscured what the organization actually could and did attain in light of the bitter experience of the Great War. Even with its many defects, the League could mediate between states that wanted a peaceful resolution to their difficulties in cooperation with great powers that feared repeating the avoidable catastrophe of 1914. It also could make it possible for states to collaborate in creating new legal methods and institutions designed to diminish the underlying causes of international conflict. The organization had the power to defuse a crisis centering on the Balkans and to keep governments from blundering into another collective tragedy that they wished to avoid and could not control. With the active support of its most influential members, it was able to carry out its main purposes 'to promote international co-operation and to achieve international peace and security'.

The League's capacity to settle international disputes of any sort, however, rapidly dissipated after 1935 as great powers abandoned it and smaller ones lost faith. This erosion of political support also severely undercut Geneva's ability to confront other threats to peace, including state-supported terrorism. Still, Geneva's two anti-terrorism conventions were significant for a number of reasons. Together, they, if ratified, might have given states a way to reduce acts of terrorism by putting greater pressure on governments that harbored terrorists, increasing international police collabo- 
ration and intelligence sharing, and making it more difficult for terrorists to acquire weapons and false passports. The League's proposals also could have given governments a means for criminalizing conspiracies to commit terrorist acts while providing an external and more neutral process for prosecuting accused terrorists.

None of this happened. The conventions never prevented or punished state-supported terrorism. Their value was mostly technical and symbolic, largely divorced from the political realities of the late 1930s. The League's legal response to terrorism was a success only in the narrowest sense and went largely unnoticed. But despite devoting decades to the subject, the United Nations too has yet to resolve many of the dilemmas that the League identified in the 1930s. ${ }^{36}$

Condemning the League as a 'failure' has obscured what the organization actually attained and why that matters. Geneva could not stop 'Hitler's War' of 1939, but it did help in 1934 to avert a repetition of the 'Great War' of 1914. Resolving the dispute between Yugoslavia and Hungary demonstrated the value of Article 11, perhaps the most effective security provision of the Covenant. The League also enabled its members to cooperate in exploring ways to combat state-supported terrorism, a problem that remains among the most important and difficult in international relations. In order to assess the Treaty of Versailles as well as Geneva's contributions to peace through law after the First World War, it is necessary to know how the League of Nations responded to international terrorism in the 1930s.

36 See United Nations Security Council Res 2178, 'Threats to international peace and security caused by terrorist acts' (24 September 2014) UNDoc S/RES/2178 (2014). 
